Acta vet. scand. 1988, 29, 249-254.

From the Department of Obstetrics and Gynaecology,

College of Veterinary Medicine, Hautjärvi, Finland.

\title{
Effect of Postpartum Live Weight Loss on Reproductive Functions in Dairy Cows
}

\author{
By K. Heinonen, E. Ettala and M. Alanko
}

\begin{abstract}
Heinonen, K., E. Ettala and M. Alanku: The effect of postpartum live weight loss on reproductive functions in dairy cows. Acta vet. scand. 1988, 29, 249-254. - Postpartum loss of live weight in dairy cows and its association with reproductive functions were studied in a total of 84 (42 Ayrshire and 42 Friesian) cows. The cows were divided according to type of feed into 2 groups of equal size: a hay-urea group and a silage group. The duration of the study was 3 years. All 84 cows were followed during their first postpartum period, 63 during 2 and 57 during 3 consecutive postpartum periods.

The resumption of ovarian function was monitored by means of a thrice weekly milk progesterone assay between calving and the first insemination.

Live weight changes during the first 30 and 60 days post partum were compared between the 2 breeds and the 2 feed groups.

After the second parturition, the mean live weight loss within 30 and 60 days post partum was roughly twice as high $(11 \%)$ as after the first $(\mathbf{4 \%})$ and third $(6 \%)$ calvings. Breed had no significant effect on weight change. The cows in the silage group lost slightly more weight after each parturition than those in the hay-urea group. Low, but statistically significant correlations were noted between weight loss post partum and reproductive functions. The interval from calving to onset of the first visible oestrus was 6 days longer, and to pregnancy 8 days longer in cows which lost more than $10 \%$ live weight within 60 days post partum than in those which lost less than $10 \%(\mathrm{p}<0.05)$. The fertility rate at first insemination $(53.1 \%)$ was lower in cows which lost more than $10 \%$ weight than in those $\mathbf{( 7 4 . 4 \% )}$ ) which lost less than $10 \%(\mathrm{p}<0.01)$. Heat detection rate was not affected by weight loss.
\end{abstract}

postpartum anoestrus; heat detection rate.

\section{Introduction}

Initiation of the oestrous cycle after parturition is delayed for a variable period of time. In dairy cows the length of that time varies from 2 to 4 weeks (King et al. 1976, Webb et al. 1980, Fonseca et al. 1983, Larsson et al. 1984). The first visible oestrus usually occurs later than the first ovulation (Whitmore et al. 1974, King et al. 1976, Larsson et al. 1984).

Loss of body condition post partum is related to delayed initiation of cyclicity in suckling cows (Echternkamp et al. 1982, Rutter \& Randel 1984) and in milking cows (Henriksen \& Jensen 1985,
Nakao et al. 1984, Ducker et al. 1985). However, loss of body weight has also been reported not to affect reproductive functions (Stevenson \& Britt 1979).

A possible hormonal background to this effect has been studied. In suckling cows which have lost condition post partum the basal LH levels are low and GnHR-induced LH secretion is below that in control animals (Echternkamp et al. 1982, Rutter \& Randel 1984, Imakawa et al. 1986). Few reports deal with pituitary secretion during negative energy balance in milking cows. Gombe \& Hansel (1973) found decreased progesterone production 
in underfed cows, but higher LH secretion than in control animals. Calculated underfeeding by comparison with feeding standards without loss of condition does not seem to affect LH secretion (Rutter \& Randel 1984).

In a preliminary report concerning the present material, neither milk yield nor calculated underfeeding seemed to have an effect on reproductive functions, but loss of body weight was associated with delayed initiation of luteal function and delayed occurrence of visible heat (Heinonen et al. 1986).

The aim of the present paper was to study the effect of 2 Finnish types of feed on body weight change after parturition and the effect of weight loss on reproductive functions.

\section{Material and methods}

The animals, management of the herd and progesterone assays have been described in detail by Heinonen et al. (1988). Forty-two Finnish Ayrshire and 32 Finnish Friesian cows were studied. A total of 204 postpartum periods were examined. All 84 cows were followed through their first postpartum period, 63 through 2 and 57 through 3 consecutive postpartum periods. The calving season was from April to August.

The cows were divided according to type of feed into 2 groups of equal size: a hay-urea group and a silage group. All animals were fed according to Finnish feeding standards: the fodder given to the hay-urea group was based on dry hay ad libitum, and that given to the silage group on grass silage ad libitum. The silage group were also given $1 \mathrm{~kg}$ dry hay daily. In addition, both groups were fed a concentrate containing $2 / 3$ barley and $1 / 3$ oats. Two per cent urea was added to the concentrate given to the hay group as a source of nitrogen. On the day of calving, the hay-urea group were given $4.8 \mathrm{~kg}$ of concentrate and the silage group $3.5 \mathrm{~kg}$. The amount of concentrate was increased at the rate of $0.3 \mathrm{~kg} /$ day for 10 days up to $7.8 \mathrm{~kg}$ /day $(6.3$ $\mathrm{kg}$ /day after the first parturition) for the hay-urea group and up to $6.5 \mathrm{~kg} /$ day $(5.0 \mathrm{~kg} /$ day after the first parturition) for the silage group. Subsequently the concentrate ration was increased according to the daily milk yield up to $12.5 \mathrm{~kg}$ /day for the hay-urea group. These rations were used at a daily milk yield of $30 \mathrm{~kg}$ or more.

The cows were milked twice a day with a 9-h interval between morning and afternoon milkings. External signs of heat were recorded 3 times a day by the herdsmen. The average milk yields of the herd were 4,162, 5,337 and 5,572 kg of 4\% FCM during lactations 1, 2 and 3, respectively.

Milk samples for progesterone assay were taken immediately after morning milking every Monday, Wednesday and Friday from calving to the first insemination. Milk was collected in plastic tubes containing $100 \mathrm{mg}$ sodium azide as a preservative. The samples were analysed within 3-4 days using a commercial RIA method (Whole milk progesterone assay, Farmos Diagnostica, Finland, Laitinen 1983).

The animals were weighed 6 days after parturition and twice a month thereafter. Body weights at 30 and 60 days post partum were extrapolated from the weight curve.

The onset of the first luteal activity (first dioestrus) was recorded when the milk progesterone value or values reached $8 \mathrm{nmol} / 1$. The first visible heat was determined as the first observed oestrus followed by an increase in milk progesterone concentration. Heat detection rate was defined as the percentage of visible heats of the heats registered with milk progesterone assay. Pregnancies were confirmed by rectal examination at 6-8 weeks post insemination. Animals which aborted later than 6-8 weeks after insemination were regarded as pregnant. Only animals with spontaneous resumption of cyclic ovarian function were included; animals treated for ovarian cyst ( 7 cases during 3 years) were excluded. 


\section{Statistical methods}

To satisfy the distributional condition of normality, logarithms of intervals from calving to initiation of luteal function and pregnancy were used in the computations.

The effect of body weight change on the reproductive functions was studied for each year/parity by means of simple regression, and differences between groups were analysed using the unpaired ttest. Categorical data were analysed using the chisquare test.

\section{Results}

The Friesians were heavier after calving than the Ayrshires; the differences between the breeds in mean weight 6 days after calving were 22.7, 38.6 and $43.1 \mathrm{~kg}$ after the first, second, and third parturitions, respectively $(p<0.01)$. There was no difference in percentage of weight change between the breeds within 30 or 60 days post partum.

The silage group were heavier after calving than the hay-urea group; the differences between the groups in mean live weight 6 days post partum were 32.0, 9.7 and $54.0 \mathrm{~kg}$ after the first, second, and third parturition, respectively $(\mathrm{p}<0.01)$. Thirty and 60 days after calving the weight loss was roughly $2 \%$ higher in the silage group than in the hay-urea group $(p<0.05)$ (with the exception that 30 days after the first calving there was no difference between the groups).
After the second calving heavier cows lost more weight than lighter cows; the correlation between postpartum live weight and percentage of weight loss within 60 days post partum was 0.42 $(p<0.001)$. No similar correlation was noted after either the first $(r=-0.04, p=0.7)$ or third parturition $(r=0.2, p=0.1)$.

The mean intervals from calving to onset of luteal function, first visible oestrus and pregnancy and the pregnancy rates at first insemination after each parturition are shown in Table 1. After the second calving the pregnancy rate at first insemination was lower $(\mathbf{4 2 . 4 \% )}$ ) in the silage group than in the hay-urea group $(60.0 \%)$.

The mean live weight 6 days post partum and weight losses within 30 and 60 days are shown in Table 2. The maximum weight loss in the entire material was $22.8 \%$ and $25.9 \%$ within 30 and 60 days post partum, respectively.

Correlations between weight loss and reproductive functions are shown in Table 3. There was a correlation between body weight loss within 60 days and interval from calving to pregnancy after each parturition, but it was statistically significant $(r=0.18, p=0.02)$ only when all postpartum periods were computed together.

Reproductive functions in cows grouped according to weight loss within 60 days post partum are presented in Table 4. Heat detection rates were similar in the cows which lost $\leq 10 \%$ weight and

Table 1. Mean intervals between calving and initiation of luteal function (1st dioestrus), 1st oestrus and pregnancy, and pregnancy rate at 1 st insemination (AI) in dairy cows of equal parity after 3 consecutive calvings. First dioestrus defined as 1st milk progesterone value of $\geq 8 \mathrm{nmol} / 1$, 1st oestrus defined as visible oestrus followed by elevation in milk progesterone.

\begin{tabular}{|c|c|c|c|c|c|}
\hline \multirow[b]{2}{*}{ Parity } & \multirow[b]{2}{*}{$\mathbf{n}$} & \multicolumn{3}{|c|}{ Interval (days) \pm SEM from calving to: } & \multirow[b]{2}{*}{$\begin{array}{c}\text { preg. } \% \\
1 \text { st AI }\end{array}$} \\
\hline & & 1st dioestrus & 1st oestrus & pregnancy & \\
\hline 1 & 84 & $32.8 \pm 1.4^{\mathrm{a}}$ & $50.3 \pm 1.7^{a}$ & $81.2 \pm 2.4^{\mathrm{a}}$ & $67.1^{\mathrm{a}}$ \\
\hline 2 & 63 & $30.2 \pm 1.6^{\mathrm{a}}$ & $42.3 \pm 2.0^{\mathrm{b}}$ & $84.5 \pm 2.8^{\mathrm{a}}$ & $51.4^{b}$ \\
\hline 3 & 57 & $28.2 \pm 1.3^{\mathrm{a}}$ & $39.3 \pm 1.9^{b}$ & $77.5 \pm 2.2^{\mathrm{a}}$ & $78.6^{\mathrm{a}}$ \\
\hline
\end{tabular}

a,b: groups with different superscripts within the same column differ significantly in terms of the variable listed $(p<0.05)$.

$\mathrm{n}=$ number of cows. 
Table 2. Mean live weight $(\mathrm{kg} \pm \mathrm{SEM}) 6$ days post partum (pp) and mean cumulative weight loss (\%) within 30 and 60 days post partum in dairy cows of equal parity after 3 consecutive calvings.

\begin{tabular}{lccrr}
\hline & & \multicolumn{2}{c}{ Weight loss (\%) } \\
\cline { 4 - 5 } Parity & $\mathrm{n}$ & Weight pp (kg) & \multicolumn{1}{c}{30 days } & \multicolumn{1}{c}{60 days } \\
\hline 1 & 84 & $467.3 \pm 4.3^{\mathrm{a}}$ & $3.8 \pm 0.4^{\mathrm{a}}$ & $4.3 \pm 0.5^{\mathrm{a}}$ \\
2 & 62 & $548.4 \pm 7.1^{\mathrm{b}}$ & $11.1 \pm 0.6^{\mathrm{b}}$ & $11.6 \pm 0.7^{\mathrm{b}}$ \\
3 & 57 & $551.6 \pm 7.8^{\mathrm{b}}$ & $5.1 \pm 0.5^{\mathrm{a}}$ & $6.8 \pm 0.7^{\mathrm{c}}$ \\
\hline
\end{tabular}

a,b,c: groups with different superscripts within the same column differ significantly in terms of the variable listed $(\mathrm{p}<0.01)$.

$\mathrm{n}=$ number of cows.

Table 3. Within-cow correlations between cumulative live weight change within 30 and 60 days post partum (days pp) and reproductive functions in dairy cows of equal parity after 3 consecutive calvings. First dioestrus defined as 1st milk progesterone value of $\geq 8 \mathrm{nmol} / 1$, 1st oestrus defined as visible oestrus followed by elevation in milk progesterone.

\begin{tabular}{lllll}
\hline & \multirow{2}{*}{$\begin{array}{l}\text { Weight } \\
\text { change } \\
\text { Parity }\end{array}$} & \multicolumn{3}{c}{ Interval from calving to: } \\
\cline { 2 - 5 } 1 & 30 & $0.23^{*}$ & 0.31 ** & 0.02 N.S. \\
& 60 & $0.30^{* *}$ & 0.14 N.S. & 0.10 N.S. \\
2 & 30 & 0.14 N.S. & $0.29 *$ & 0.18 N.S. \\
& 60 & 0.13 N.S. & $0.30^{*}$ & 0.18 N.S. \\
3 & 30 & 0.18 N.S. & 0.08 N.S. & 0.11 N.S. \\
& 60 & 0.24 N.S. & 0.18 N.S. & 0.23 N.S. \\
\hline
\end{tabular}

$*=\mathrm{p}<0.05$

$* *=p<0.01$

N.S. = not significant. those with $>10 \%$ which lost: $13.9 \%$ and $9.0 \%$ before the first and $75.5 \%$ and $74.7 \%$ before the second dioestrus, respectively.

\section{Discussion}

Because the Friesians were heavier at calving than Ayrshires, and since the percentage weight losses were roughly the same, the Friesians lost more weight. In spite of this no differences in post partum reproductive functions were noted between the breeds in an earlier study involving the same cows (Heinonen et al. 1988).

Postpartum reproductive functions of the 2 groups of feed were also similar (Heinonen et al. 1988). The only difference was in fertility rate at first insemination after the second calving, which was slightly, although not significantly, lower in the silage group (42.4\%) than in the hay-urea group $(60.0 \%)$. This may be a reflection of the more prominent weight loss among cows in the silage group.

After the second calving, but not after the first or third, there was a strong correlation between body weight at calving and weight loss within 60 days post partum. This indicates that, under certain conditions heavier cows lose more weight during the first months of lactation than lighter ones. One factor predisposing to weight loss could be fatness at calving. In the present study body weight could not be used to evaluate fatness since all cows were of the same age and the effect of year and parity could not be separated. However, after

Table 4. Mean intervals (days \pm SEM) from calving to first dioestrus, oestrus and pregnancy and pregnancy rates at first insemination (AI) in dairy cows after 3 consecutive calvings grouped according to weight loss within 60 days post partum. First dioestrus defined as 1st milk progesterone value of $\geq 8 \mathrm{nmol} / 1$, 1st oestrus defined as oestrus followed by elevation in milk progesterone.

\begin{tabular}{lrrrrr}
\hline \multirow{2}{*}{$\begin{array}{l}\text { Weight } \\
\text { loss }\end{array}$} & $\mathrm{n}$ & \multicolumn{3}{c}{ Interval (days) \pm SEM from calving to: } & preg. \% \\
\cline { 3 - 6 } & \multicolumn{1}{c}{ 1st dioestrus } & 1st oestrus & pregnancy & 1st AI \\
\hline $5 \%$ & 63 & $29.7 \pm 1.6$ & $45.7 \pm 2.1$ & $78.6 \pm 2.5$ & 78.6 \\
$\leq 10 \%$ & 134 & $30.6 \pm 1.1$ & $42.8 \pm 1.3$ & $79.4 \pm 1.7$ & 74.4 \\
$>10 \%$ & 55 & $34.5 \pm 1.9$ & $48.3 \pm 2.5^{*}$ & $87.9 \pm 3.2^{*}$ & $53.1^{*}$ \\
\hline
\end{tabular}

* Weight loss in this group differs significantly $(\mathrm{p}<0.05)$ from that in the other postpartum periods. $\mathrm{n}=$ number of postpartum periods. 
the second parturition the cows were obviously in rather good body condition by comparison with the first or third. They gained roughly $80 \mathrm{~kg}$ in weight between the first and second calvings, but gained none between the second and the third. Finnish Airshyre cows have been reported to gain 25-30 $\mathrm{kg}$ between subsequent parturitions during the first 4 lactations (Rainio 1987). Further research is needed to determine to what degree post partum loss of body condition could be avoided by preventing fatness at calving.

Weight loss within 60 days seemed to correlate slightly better with each variable studied than weight loss within 30 days, although weight loss did not increase much between 30 and 60 days post partum. The mean percentage weight loss after the second parturition was twice that after the first or third. This could be reflected in reproductive functions after the second calving as a low fertility rate at first insemination. This is supported by the finding that cows which lost more than $10 \%$ weight within 60 days had a low pregnancy rate at first insemination.

The strongest correlation between body weight loss and length of the postpartum acyclic period was noted after the first calving, not after the second when weight loss was most prominent. One explanation could be that after the first calving the cows were still growing, which would emphasize the effect of weight loss. Delayed onset of visible heat in cows which had lost more than $10 \%$ weight within 60 days seemed to be caused by delayed initiation of luteal function, and not by a decreased heat detection rate. Ducker et al. (1985) also found that heat detection rate was not affected by level of feeding.

Weight loss seemed to be associated with an increased interval from calving to pregnancy: there was a low positive correlation between weight loss and days open when all postpartum periods were computed together. The cows with more than $10 \%$ weight loss had slightly more days open than those which lost less than $10 \%$. However, also cows with more than $10 \%$ weight loss had a mean calving interval of about 1 year. If the effect of weight loss were to continue linearly, more than $10 \%$ would be permissible without economically disadvantageous prolongation of the calving interval.

It is concluded that both types of feed were equally effective in enabling the cows to maintain their body weight during the first months of lactation irrespective of breed. Weight loss of more than $10 \%$ within 60 days post partum tended to be associated with an increased interval from calving to first visible oestrus, pregnancy and decreased fertility rate at first insemination. Weight loss was not associated with a decreased heat detection rate.

\section{References}

Ducker MJ, Haggett R, Fisher WJ, Morant SV, Bloomfield $A$ : Nutrition and reproductive performance of dairy cattle. 1 . The effect of level of feeding in late pregnancy and around the time of insemination on the reproductive performance of first lactation dairy heifers. Anim. Prod. 1985, 41, 1-12.

Echternkamp SE, Ferrell CL, Rone JD: Influence of preand post-partum nutrition on $\mathrm{LH}$ secretion in suckled postpartum beef heifers. Theriogenology 1982, 18, 283-295.

Fonseca FA, Britt JH, McDaniel BT, Wilk JC, Rakes $A H$ : Reproductive traits of Holsteins and Jerseys. Effects of age, milk yield, and clinical abnormalities on involution of cervix and uterus, ovulation, estrous cycles, detection of estrus, conception rate, and days open. J. Dairy Sci. 1983, 66, 1128-1147.

Gombe S, Hansel W: Plasma luteinizing hormone (LH) and progesterone levels in heifers on restricted energy intakes. J. Anim. Sci. 1973, 37, 728-733.

Heinonen $K$, Alanko $M$, Ettala $E$ : Effects of feeding during the postpartum period on the genital function of dairy cows. Proc. XV Nordiska Veterinärkongressen, Stockholm 1986, 2376-240.

Heinonen $K$, Savolainen $E$, Tuovinen $V$, Miettinen $P$, Alanko M: Postpartum reproductive function in Finnish Ayrshire and Friesian cows after three subsequent parturitions. Acta vet. scand. 1988, 29, preprint.

Henriksen J, Jensen M: Studies on the endocrine and environmental factors influencing post partum 
acyclicity in dairy cows based on progesterone profile (preliminary results). Endocrine causes of seasonal and lactational anestrus in farm animals. Martinus Nijhoff Publishers 1985, p. 221-232.

Imakawa $K$, Day ML, Zalesky DD, Garcia-Winder $M$, Kittok RJ, Kinder JE: Influence of dietary-induced weight changes on serum luteinizing hormone, estrogen and progesterone in the bovine female. Bio. Reproduc. 1986, 35, 377-384.

King GJ, Hurnik JF, Robertson HA: Ovarian function and estrus in dairy cows during early lactation. J. Anim. Sci. 1976, 42, 688-692.

Laitinen J: Oestrus confirmation, pregnancy diagnosis and post-partum follow up of the Finnish dairy cows by milk progesterone assay: Effect of breed, season, feed and sampling on milk progesterone levels. Thesis. Publications of the University of Kuopio Natural Sciences Original Reports 1983, 1, 39-40.

Larsson $K$, Jansson L, Berglund B, Edqvist L-E, Kindahl $\mathrm{H}$ : Postpartum reproductive performance in dairy cows. I: Influence of animal, breed and parity. Acta vet. scand. 1984, 25, 445-461.

Nakao T, Yoshimeki S, Moriyoshi M, Kawata K: Effect of energy and protein intake on ovarian activity in postpartum high-producing Holstein cows. Proc. 10th Int. Congr. Anim. Repr. And A.I., Illinois 1984, vol. II, p. 803-808.

Rainio V: Unpublished data 1987.

Rutter LM, Randel RD: Postpartum nutrient intake and body condition: effect on pituitary function and onset of estrus in beef cattle. J. Anim. Sci. 1984, 58 , 265-274.

Stevenson SJ, Britt JH: Relationship among luteinizing hormone, estradiol, progesterone, glucocorticoids, milk yield, body weight and postpartum ovarian activity in Holstein cows. J. Anim. Sci. 1979, 48, 570-577.

Webb R, Lamming GE, Haynes NB, Foxcroft GR: Plasma progesterone and gonadotrophin concentrations and ovarian activity in post-partum dairy cows. J. Repr. Fert. 1980, 59, 133-143.
Whitmore HL, Tyler WJ, Casida LE: Effects of early postpartum breeding in dairy cattle. J. Anim. Sci. 1974, 38, 339-346.

\section{Sammanfattning}

Inverkan av postpartum viktminskning på reproduktiva funktioner hos mjölkkor.

Postpartum vikminskning hos mjölkkor samt dess samband med de reproduktiva funktionerna undersöktes.

Totalt 84 kor (42 Ayrshire och 42 Frisiska) undersöktes. Korna indelades i två lika stora grupper som gavs olika foder: en hö-urea grupp och en ensilagegrupp. Undersökningen varade i 3 ár. Alla 84 kor undersöktes under en (deras första) postpartum period, 63 under 2 och 57 under 3 pávarandra följande postpartuma perioder. Ovariefunktionernas återkomst granskades med hjälp av progesteronprov ur mjölk, 3 gånger i veckan under tiden mellan kalvning och den första insemineringen.

Viktförändringarna under de 30 och 60 första postpartuma dygnen jämfördes mellan raserna och fodergrupperna.

Efter den andra kalvningen var viktminskningen under de 30 och 60 första postpartuma dygnen grovt räknat dubbelt så hög (11\%) som efter den första (4\%) och den tredje $(6 \%)$ kalvningen. Kornas ras hade ingen signifikant inverkan på viktförändringen. Korna i ensilagegruppen förlorade en aning mer vikt efter varje kalvning än korna i hö-ureagruppen. Låg men statistiskt signifikant korrelation mellan postpartum viktminskning och de reproduktiva funktionerna noterades. Tiden mellan kalvning och första tydliga estrus var 6 dagar längre och tiden till dräktighet 8 dagar längre hos kor som förlorat mera än $10 \%$ av sin vikt under 60 dygn postpartumt än hos kor som förlorat mindre än $10 \%$ av sin vikt $(p<0,05)$. Fertilitetsprocenten vid den första inseimnationen $(53,1 \%)$ var lägre bland kor som förlorat mer än $10 \%$ av sin vikt än bland de kor $(74,4 \%)$ som förlorat mindre än $10 \%$ av sin vikt $(\mathrm{P}<0,01)$. Den procentuella andelen upptäckta estrus påverkades inte av viktminskning.

(Received December 10, 1987).

Reprints may be requested from: Kalevi Heinonen, Department of Obstetrics and Gynaecology, College of Veterinary Medicine, SF-04840 Hautjärvi, Finland. 